\title{
Cytogenetic Pattern of Acute Lymphoblastic Leukemia (ALL) in the Yogyakarta and Central Java Province, Indonesia
}

\author{
Sofia M. Haryana*, E.Suryadi**, Sultana M. Husein***, Radjiman*
}

\begin{abstract}
ABSTRAK
Penelitian ini bertujuan untuk melihat gambaran sitogenetika penderita ALL (Acute Lymphoblastic Leukemia). Gambaran sitogenetika ini penting untuk menentukan penatalaksanaan penderita tersebut. Empat belas pasien ALL yang berobat ke rumah sakit di Yogyakarta dan Semarang sejak Juni 1992 sampai November 1992 telah diperiksa gambaran sitogenetikanya dengan metode $G$-banding. Hasil pemeriksaan menunjukkan 4 penderita dengan kelainan struktural kromosom berupa $t(9 ; 22)(q 34.1 ; q 11.21)$ pada 2 pasien, $t(4 ; 11)$ (q23) pada 1 pasien, del 11, p13-14 pada 1 pasien; 9 penderita dengan kelainan jumlah kromosom berupa hiperploidi, poliploidi, tetraploidi, atau monosomi, 3 diuntarany a termasuk kelainan kromosom ganda (struktural dan numerikal); 4 penderita tidak ditemukan kelainan kromosom. Pada penderita dengan hanya hiperploidi > 50 kromosom dan gambaran sitogenetika normal setelah pengobatan menunjukkan remisi/remisi parsialis. Sedangkan 3 penderita dengan kelainan kromosom ganda menunjukkan perjalanan penjakit lebih progresif. Disimpulkan bahwa kelainan struktural pada ALL mempunyai arti penting dalam menentukan penggolongan dan prognosis penyakit.
\end{abstract}

\begin{abstract}
The aim of this investigation is to analyse the cyrogenetics of ALL patients. Cytogenetic analysis is important in determining the management of those patients. Fourteen ALL patients, hospitalised in several hospirals in Yogyakarta and Semarang since June 1992 to November 1992 , were studied by $G$-banding method. The results showed 4 patients with structural abnormality $1(9 ; 22)(q 34.1 ; q 11.21)$ (2 patients), $1(4 ; 11)(q 21 ; q 23)$ (1 patient), and del 11, p13-p14 (1 patient); 9 patient with numerical abnormality such as hyperploidy. polyploidy, tetraploidy and monosomy, three of them showed double abnormalities (structural and numerical); 4 patients with normal karyotype. Patients wich previously have hyperploidy $>50$ chromosom and normal kanyotype, afier treatment showed remission/partial remission. Patirnts with double abnormalities were clinically more progressive. It is concluded that structural chromosomal abnormality in ALL is important to determine the group and prognosis of the disease.
\end{abstract}

Key words: ALL-cyrogenetics - translocation - deletion -hyperploidy-classification - prognosis.

\section{INTRODUCTION}

Cancer is the result of accumulation of multiple genetic changes.' Each alteration, whether an initiating or a progression event, may be mediated through a gross chromosal change and therefore has the potential to be cytogenetically visible. ${ }^{2}$

The common tumor schromosomal abberrations are classified as structural or numeric. Structural alterations include translocations, inversions, deletions, insertions and amplifications, whereas numerical abnormalities are losses or duplication of whole chromosomes. 3 In hematological malignancy such as leukemia, analysis of the chromosomes also has been extensively studied, which revealed that almost all leukemia carry a karyotype abnormality.

Hematological malignancy particularly leukemia is still a problem in Indonesia. Cases recorded at Dr. Sardjito Hospital in the Yogyakarta province from 1987 to 1990 included Hodgkin lymphoma (6.29\%),

* Department of Histology, Faculty of Medicine, Gadjah Mada University, Yogyakarta, Indonesia

** Department of Anatomy, Faculty of Medicine, Gadjah Mada University, Yogyakarta, Indonesia

*** Department of Histology, Faculty of Medicine, Diponegoro Universiny, Semarang, Indonesia 
non Hodgkin lymphoma (46.85\%), multiple myeloma (3.14\%), lymphoid leukemia $(21.86 \%)$, myeloid leukemia $(19.86 \%)$ and other types of leukemia $(1.98 \%){ }^{4}$ The frequency of malignancy cases from year to year was increasing. In 1987 there were 884 cases, in 19881164 cases, in 19891190 and in 1990 1282 cases. The total number of malignancy cases at Dr. Sardjito Hospital Yogyakarta were 4520 cases. ${ }^{4,5}$ In Semarang, Sunjoyo reported that there were 84 cases of hematological malignancies between 19841986, included non Hodgkin lymphoma (42.9\%), myeloid leukemia (32.4\%), lymphoblastic leukemia $(17.2 \%)$, multiple myeloma $(3.7 \%)$ and Hodgkin lymphoma $(2.3 \%){ }^{6}$

The diagnosis of leukemia in Yogyakarta or Indonesia in general is based on the morphological finding of blood lineage cells, in blood or bone marrow smear stained with routine staining such as Giemsa, Wright, May Grunwald, and examined under regular light microscope (FAB Classification). ${ }^{5}$

Therapy using standard regimen therapy showed no satisfactory results; ${ }^{5}$ this may be due to the timing of patients arrival at the hospital. Usually patients came to the hospital at the terminal state of the disease or might be due to innaccuracy of diagnosis. In 1988 a group of hematologist proposed a new classification of leukemia based on morphology, immunophenotyping and citogenetics (MIC). 7 Classification which merely based on morphology could not classify the type of leukemia. ${ }^{7}$ Using cytogenetic analysis will increase the accuracy of the diagnosis, so that the therapy can be determined and the prognosis can be predicted. ${ }^{8,9,10}$ In Indonesia, the diagnosis of leukemia using cytogenetic analysis has not been routinely used.

The aim of this study is to analyse the cytogenetic pattern of ALL patients in Yogyakarta and Central Java, Indonesia, in the hope that therapy could be correctly given to the patient and prognosis of the disease can be predicted.

\section{MATERIALS AND METHODS}

\section{Samples}

One $\mathrm{ml}$ of heparinized peripheral blood and $0.5 \mathrm{ml}$ of bone marrow aspirate from patients diagnosed as leukemia at Dr. Sardjito Hospital (Yogyakarta), Kariadi Hospital (Semarang), and Telogorejo Hospital (Semarang).

\section{Methods}

Arresting : Colcemid was used in this investigation as arresting agent to stop mitosis at metaphase. ${ }^{3}$ Colce- mid is a mitotic spindle inhibitor, which can block the formation of spindle fibres. Normally, spindle fiber was attached to the centromere of each chromosome before mitotic division and pull the chromatids apart by contraction at anaphase. ${ }^{3}$

Hypotonic Shock : The hypotonic solution used was $0.075 \mathrm{M} \mathrm{KCL}$ since it has been known, that this solution is the least damaging to chromosomes substructure. A hypotonic solution is a solution with a lower salt concentration than that of the cytoplasm of cells, so there will be a movement of $\mathrm{H}_{2} \mathrm{O}$ from the hypotonic solution into the cell. ${ }^{3}$

Fixation : The fixative solution was freshly made of 3 parts of absolute methanol to 1 part of glacial acetic acid. The volatile alcohol plays a role in flattening and spreading the chromosomes during air drying. Glacial acetic acid will rupture the membrane of the cell.

Slide Preparation and Staining: Slides were washed in distilled water, dried at room temperature and stained with Giemsa. ${ }^{11}$

\section{Giemsa Staining and Banding}

Giemsa staining is a method to stain the chromosomes. Giemsa stain is a Romanowsky-type dye mixture. Azure B and eosin in the Giemsa bound to DNA. "The solutions needed are :

1. Giemsa stain concentrate, made by adding $1.0 \mathrm{~g}$ Giemsa powder to $66 \mathrm{ml}$ methanol and $66 \mathrm{ml}$ glycerin, stirred for 2 days at room temperature, prepared at least 2 weeks before use. Stored in a dark container in a refrigerator.

2. Phosphate buffer ( $\mathrm{pH}$ 6.8), which consists of $0.025 \mathrm{M} \mathrm{KH}_{2} \mathrm{PO}_{4}(3.4 \mathrm{~g} / \mathrm{l})$, and the $\mathrm{pH}$ was adjusted using $50 \% \mathrm{NaOH}$.

Giemsa staining solution was prepared by mixing $5 \mathrm{ml}$ of Giemsa stain concentrate and $45 \mathrm{ml}$ of phosphate buffer (pH 6.8).

Giemsa banding ( $\mathrm{G}$ banding) is a method to obtain bands in chromosomes by treating slides with a protease such as trypsin or incubate the slides in hot salinecitrate. The chromosome banding pattern obtained reflects both structural and functional composition of the chromosomes. ${ }^{10,11}$

Solutions needed are :

1. Giemsa stain concentrate

2. Phosphate buffer ( $\mathrm{pH} 6.8$ )

3. Trypsin-EDTA $10 \mathrm{X}$ concentrate (trypsin $(1: 250) 5$ $\mathrm{g} / \mathrm{l}$ and EDTA $2 \mathrm{~g} / \mathrm{l}$ ). 
Working staining solution is prepared by mixing $26 \mathrm{~m} !$ buffer (pH 6.8), $7 \mathrm{ml}$ methanol, 0.6-1.0 $\mathrm{ml} 10 \mathrm{X}$ trypsin EDTA and $0.8 \mathrm{ml} \mathrm{Giemsa} \mathrm{stain} \mathrm{concentrate.}$

\section{Chromosome Analysis}

Chromosomes are prepared by direct bone marrow and peripheral blood culture developed in our laboratory. Marrow cells were cultured in RPMI- 1640 medium supplemented with $15 \%$ fetal calf serum. Only \pm 0.1 $\mathrm{ml}$ of sedimented cells were processed from each centrifuge tube. The cells were exposed to colcemid $(0.06 \mathrm{mg} / \mathrm{ml})$ for 25 minutes and then to hypotonic solution i.e. $\mathrm{KCl}(0.075 \mathrm{~mol} / \mathrm{l})$ for a total of 32 minutes (including mixing, standing and centrifuge time). Slides were fixed in 3:1 methanol acetic acid $(v / v)$ and dried on a hot plate. Slides were subjected to Giemsa staining and banding.

For each case, 10-20 metaphases (mean 15) were studied by direct microscopy to determine the modal number and to identify the malignant stem line. Karyotype were prepared from photographic prints. Chromosomal abnormalities were classified according to the International Conventions. ${ }^{10,11,12}$ The definition of an abnormal stem line was defined according to that proposed by the Second International workshop on chromosome in leukemia. A case was considered abnormal if it had an abnormal clone, regardless of the proportion of normal metaphase. ${ }^{13}$

\section{RESULTS}

The patients were diagnosed when they were hospitalised. There were 14 patients analysed cytogenetically. Out of those 14 patients 8 were males and 6 were females (Table 1). The range of the age was between 2-20 years old. There were 4 patients under 5, 7 patients between 5 and 12 , and 3 patients more than 12 years old (Table 2 ). The diagnosis was based on FAB classification (morphology) by Wright or Giemsa staining.

Table 1. Patients with ALL

\begin{tabular}{lcc}
\hline Sex & $\mathrm{n}$ & $\%$ \\
\hline Male & 8 & 57.1 \\
Female & 6 & 42.9 \\
\hline Total & 14 & 100 \\
\hline
\end{tabular}

$\mathrm{n}=$ number of patient
The cytogenetic analysis on peripheral blood and bone marrow samples were carried out on at least 10 metaphases from one slide. The findings were as follows (Table 2) :

- 1 patient of $46 \mathrm{XY}, \mathrm{t}(4 ; 11)$ (q21;q23) from peripheral blood and $53 \mathrm{XXY}$ from bone marrow.

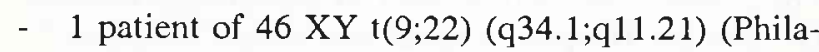
delphia chromosome positive) from peripheral blood and $56 \mathrm{XY}$ from bone marrow.

- 1 patient of $\mathrm{t}(9 ; 22)$ (q34.1;q11.21) from peripheral blood, $\mathrm{Ph}+$ from bone marrow.

- 7 patients of abnormality in chromosome number from bone marrow i.e. $52 \mathrm{XY}$ mozaic, $91 \mathrm{XX}$ polyploidy mozaic, hyperploidy $>50$ chromosomes mozaic, $87 \mathrm{XY}$ polyploidy mozaic $(25 \%), 92$ XXYY tetraploidy mozaic, and monosomies 45 $\mathrm{XX}-7$ and $45 \mathrm{XY}-17$.

- 4 patients showed no structural and numerical chromosome abnormality.

Table 2. Age, Sex, Cylogenelic linding of ALL

\begin{tabular}{|c|c|c|c|c|}
\hline $\begin{array}{l}\text { No.of } \\
\text { patient }\end{array}$ & $\begin{array}{c}\text { Age } \\
\text { (years) }\end{array}$ & Sex & Cylogenetic linding & Source \\
\hline 1. & 4 & M & $46 \mathrm{XY}$, mozaic, $52 \mathrm{XY}$ & $\mathrm{BM}$ \\
\hline 2. & 4 & $\mathrm{~F}$ & $46 \mathrm{XX}$, mozaic, $91 \mathrm{XX}$ polyploidy & $\mathrm{BM}$ \\
\hline 3. & 5 & $\mathrm{~F}$ & $46 \times X$ & \\
\hline 4. & 6 & M & $\begin{array}{l}46 \times Y(1 ; ; 11)(q 21 . q 23) / 53 \times X Y \\
(4+1 ; 5+1 ; 6+1 ; 11+1 ; 16+1 ; 21+1 ; X+1)\end{array}$ & $\mathrm{P} / \mathrm{BM}$ \\
\hline 5. & 5 & $\mathrm{~F}$ & $45 \times X-7$ & BM \\
\hline 6. & 3 & $\mathrm{M}$ & $\begin{array}{l}46 \times Y 1(9 ; 22)(q 34.1 . q 11.21)\left(\mathrm{Ph}^{+}\right) / \\
56 \times Y \text { lyperploidy }(5+1)(6+1)(8-1) \\
(13+1)(14+1)(16+1)(17-1)(18+2) \\
(21+3)(22+2)\end{array}$ & $\mathrm{P} / \mathrm{BM}$ \\
\hline 7. & 20 & $\mathbf{M}$ & $46 \mathrm{XY}$, hyperploidy > 50 Chromosome & $\mathrm{BM}$ \\
\hline 8. & 6 & M & $46 X Y$ & \\
\hline 9. & 11 & $\mathbf{M}$ & $46 X Y, 87 X Y$ polyploidy $25 \%$ & $\mathrm{BM}$ \\
\hline 10. & 4 & $F$ & 46 XY $1(9 ; 22)(q 34.1 . q 11.2) / P h+$ & $\mathrm{P} / \mathrm{BM}$ \\
\hline 11. & 9 & $\mathbf{F}$ & $46 \mathrm{XX}$ & \\
\hline 12. & 6.5 & $\mathrm{~F}$ & $46 \times X$ & \\
\hline 13. & 20 & M & $46 \mathrm{XX}, 92 \mathrm{XXYY}$ tctraploidy & $\mathrm{BM}$ \\
\hline 14. & 19 & M & $45 \times Y-17$ del $11, p 13-p 14$ & $\mathrm{BM}$ \\
\hline
\end{tabular}

$\mathrm{BM}=$ source of karyolyping analysis is trom bone marrow

$\mathrm{P} / \mathrm{BM}=$ source of karyolyping analysis is from bone marrow and peripheral blood

$\mathrm{M}=$ male

$\mathrm{F}$ = female 
Table 3. The Impact of cytogenetic finding and outcome

\begin{tabular}{|c|c|c|}
\hline No. of patient & Cytogenetic finding & Outcome \\
\hline 1. & abN (num) & ND \\
\hline 2. & abN (num) & Remission \\
\hline 3. & $\mathbf{N}$ & Remission \\
\hline 4. & $a b N(s t r+n u m)$ & $\mathrm{D}$ \\
\hline 5. & $\mathrm{abN}$ (num) & Remission $\longrightarrow \mathrm{D}$ \\
\hline 6. & $a b N(s t r+n u m)$ & $\mathrm{D}$ \\
\hline 7. & $a b N$ (num) & Remission \\
\hline 8. & $\mathrm{~N}$ & D \\
\hline 9. & $\mathrm{abN}$ (num) & ND \\
\hline 10. & $a b N(s t r)$ & p.Remission $\longrightarrow$ D \\
\hline 11. & $\mathrm{~N}$ & Remission \\
\hline 12. & $\mathrm{~N}$ & Remission \\
\hline 13. & abN (num) & ND \\
\hline 14. & $a b N(s t r+n u m)$ & D \\
\hline $\begin{array}{l}\mathrm{abN}=\text { abnormal } \\
\mathrm{N}=\text { normal }\end{array}$ & $\begin{array}{l}\mathrm{ND}=\text { no follow up } \\
\mathrm{D}=\text { died }\end{array}$ & $\begin{array}{l}\text { str }=\text { struclural } \\
\text { num }=\text { numerical }\end{array}$ \\
\hline
\end{tabular}

No follow up patients $(21.4 \%)$; complete remission (35.7\%) and died $(42,86 \%)$.

$\begin{array}{lll}-\mathrm{N} & \text { - remission } & 3 \text { patients : } 21.4 \% \\ - \text { abN } & \text { - remission } & 3 \text { patients : } 21.4 \% \\ -\mathrm{N} & \text { - died } & 1 \text { patient : } 7.14 \% \\ - \text { abN } & \text { - died } & 5 \text { patients : } 35.71 \%\end{array}$

Table 4. Age and karyotype abnormality

\begin{tabular}{crl}
\hline No.of patient & Age & \multicolumn{1}{c}{ Karyotype N/abN } \\
\hline 1. & 4 & $\mathrm{abN}$ (numerical,gain) \\
2. & 4 & $\mathrm{abN}$ (numerical,gain) \\
3. & 5 & $\mathrm{~N}$ \\
4. & 6 & $\mathrm{abN}$ (structural+numerical,gain) \\
5. & 5 & $\mathrm{abN}$ (numerical,loss) \\
6. & 3 & $\mathrm{abN}$ (structural+numerical,gain) \\
7. & 20 & $\mathrm{abN}$ (numerical,gain) \\
8. & 6 & $\mathrm{~N}$ \\
9. & 11 & $\mathrm{abN}$ (numerical,gain) \\
10. & 4 & $\mathrm{abN}$ (structural) \\
11. & 9 & $\mathrm{~N}$ \\
12. & 6.5 & $\mathrm{~N}$ \\
13. & 20 & $\mathrm{abN}$ (numerical,gain) \\
14. & 19 & $\mathrm{abN}$ (structural+numerical,loss)
\end{tabular}

\footnotetext{
Abnormal karyotype : Age under 5 years : 4 patients (40\%)

5 - 12 years : 3 patients $(30 \%)$

$>12$ years : 3 patients (30\%)

Normal karyotype : Age under 5 years : - $(0 \%)$

$$
\begin{gathered}
5-12 \text { years : } 4 \text { patients }(100 \%) \\
>12 \text { years : - } \quad(0 \%)
\end{gathered}
$$
}

Proportion of ahnormal karyotype : high incidence under 5 years.

\section{DISCUSSION}

The data obtained from the Third International workshop on chromosome in Leukemia, comprising 330 children and adults with ALL showed that the specific karyotype patterns provided significant independent prognostic information, in regard to remission duration and survival. ${ }^{10,11,13,14}$

Our investigation consisted only of 14 ALL patients, which was very small to asses the impact of the karyotype on the progressiveness of the disease. But we hope it might give a general idea of the pattern of cytogenetics in Central Java and Yogyakarta province.

Our findings showed several translocations. Translocation of $\mathrm{t}(4 ; 11)$ ( $\mathrm{q} 21 ; \mathrm{q} 23)$ was found in 1 patient. This type of translocation was common in congenital ALL and ALL in young infants. ${ }^{15}$ Translocation of $\mathrm{t}(4 ; 11)$ has also been reported related to exposure to carcinogens. ${ }^{16}$ Two patients showed translocation of $\mathrm{t}(9 ; 22)$ (q34.1; 11.21$)$ called $\mathrm{Ph}+\mathrm{Ph}+$ commonly occurs in ALL besides CML (chronic myeloid leukemia), and about $6 \%$ occurs in children. ${ }^{9,15}$ Translocation of $t(4 ; 11)$ and $t(9 ; 22)$ indicate a very poor prognosis. ${ }^{14,16}$ Those patients after an inductive remission showed a partial remission but then they were hospitalized with CNS (central nervous system) leukemia and died of cerebral bleeding. Hyperploidy with chromosome number of $470-50$ or $>50$ is commonly associated with $\mathrm{B}$ lineage and rare in Tlineage ALL. ${ }^{14}$ Some of the patients also showed hyperploidy more than 50 chromosome, but we are not sure whether these patients were of B lineage, since immunophenotyping has not been performed.

Hyperploidy indicated good prognosis especially in mozaic with normal karyotype. ${ }^{8,9}$ In this study we found five patients with normal karyotype or in mozaic with hyperploidy, achieved complete remission; they were 3 patients with normal karyotype, 1 patient with normal karyotype and hyperploidy (mozaic) and 1 patient with polyploidy. One patient with monosomi-7 achieved short remission and then died. While 3 patients which consists of 1 patient with hyperploidy (mozaic), 1 patient with polyploidy $25 \%, 1$ patient with tetraploidy (mozaic) could not be followed up. This finding indicates that cytogenetic analysis has an important role in predicting the prognosis and also in determining the high risk group from general population. Patients with chromosome abnormalities especially with translocation or deletion of whole chromosome (monosomy) should be categorized as high risk patient eventhough $\mathrm{Hb}, \mathrm{WBC}$ and total platelets were in normal range, and regimen therapy chosen should be given intensively. 

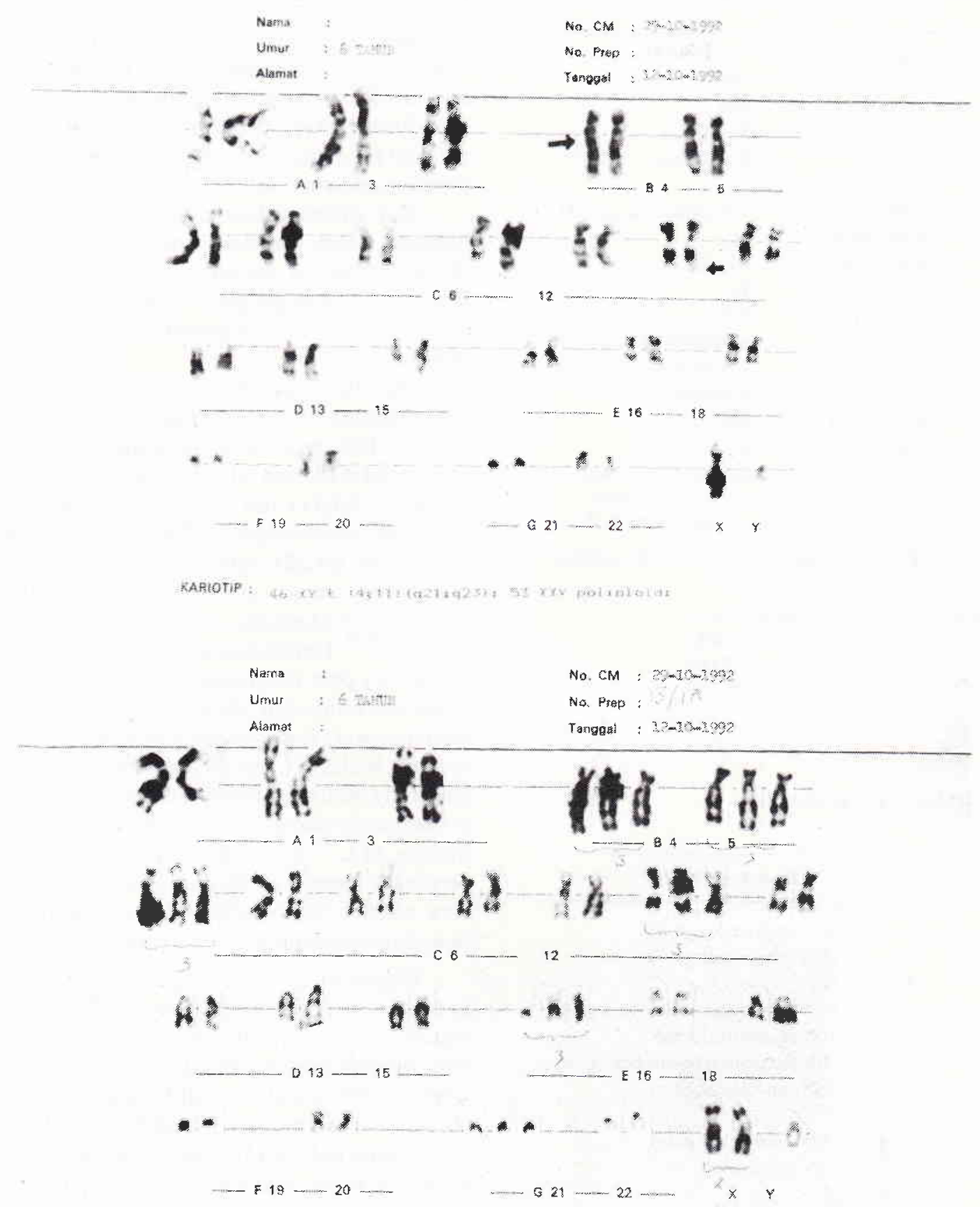

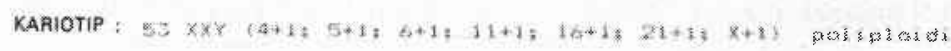

Figure 1. Karyotype of an ALL-L1 patient showing

a) $46 X Y, t(4 ; 11)(q 21 ; q 23)$ and

b) 53 XXY from bone marrow culture

Karyotyping was done from G-banded chromosome

$t=$ translocation $q=$ long arm of the chromosome

$G=$ Giemsa

ALL-LI = Acute lymphoblastic leukemia type $L-1$ 

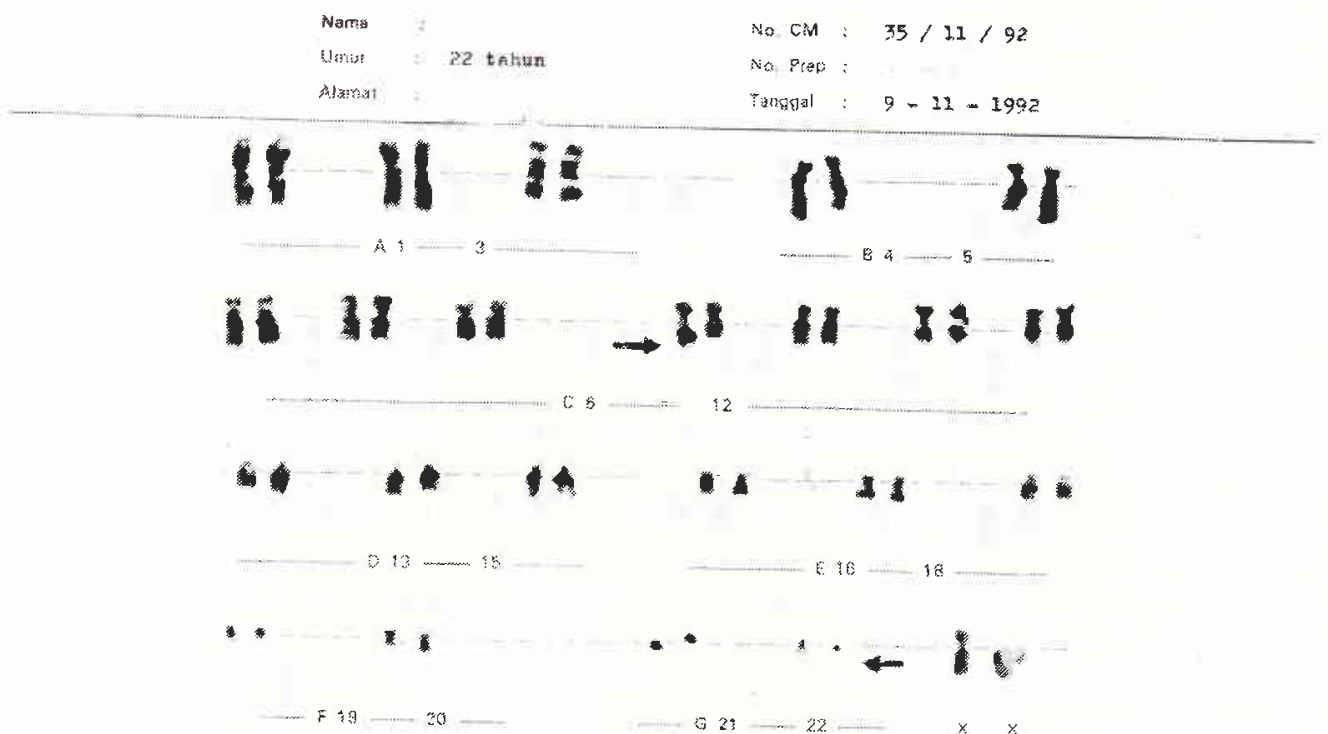

KABIOTIP :

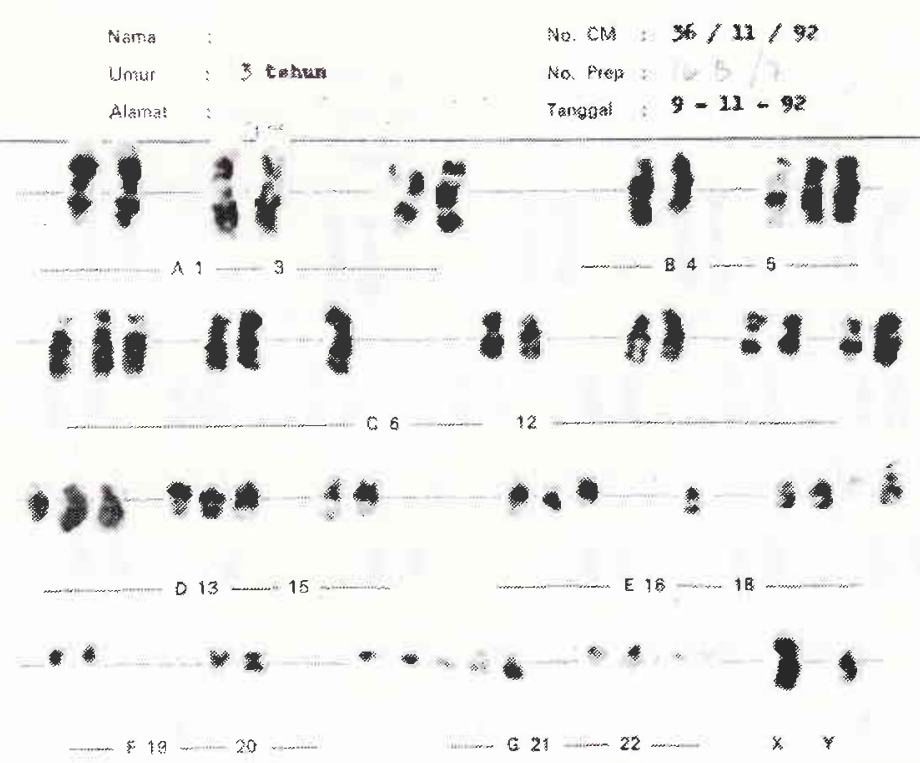

KATOTE

Figure 2. Karyotype of an $A L L-L 1$ patient showing

a) $46 X Y, t(9 ; 22)(q 34 ; q 11.21)(P h+)$ and

b) $56 X Y$ (poliploidy)

Karyotyping was done from G-banded chromosome

$t=$ translocation $q=$ long arm of the chromosome

$\left(P h^{+}\right)=$Philadelphia chromosome positive

$G=$ Giemsa

$A L L-L I=$ Acute lymphoblastic leukemia type $L-1$ 

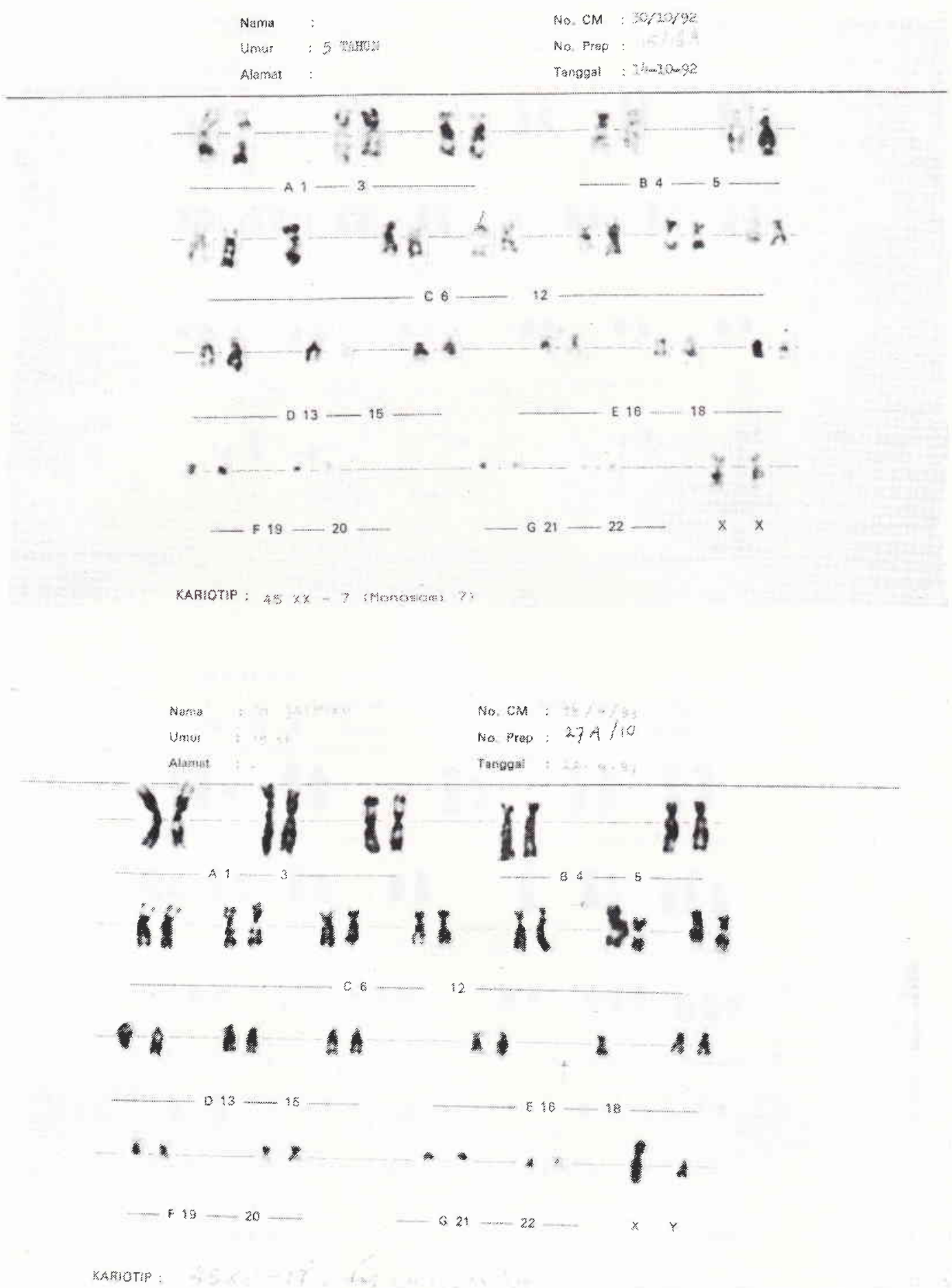

Figure 3. Karyotyping of two ALL-L1 patient showing

a) monosomy $46 X X-7$ and

b) monosomy $45 X Y-17$

karyotyping was done from $G$-banded chromosome

$G=$ Giemsa

$A L L-L 1=$ Acute lymphoblastic leukemia type $L-I$ 


\section{CONCLUSION.}

Our results suggested that multiple abnormalities and monosomies indicate poorer prognosis compare to hyperploidy, poliploidy and normal karyotype.

Patients with translocation or deletion of whole chromosome should be categorized as high risk patients regarldless the $\mathrm{Hb}, \mathrm{WBC}$ and platelets count.

\section{Acknowledgement}

We thanked Prof T.Tokuhisa, Kobe University Medical School for his valuable correction and critics. We also thank the assistance of Wiwied, Suwarsih, Maya and Ani for the technical works; Sudaryono for typing the manuscript; the Director of Telogorejo Hospital and the Director of the Live Science Laboratory of Gadjah Mada University for providing the facilities needed for this work. To Prof. Dr. A.G. Sumantri, Faculty of Medicine Diponegoro University, who has been very supportive in managing the collaboration between GMU and Diponegoro University, we wish to express our sincere thanks. We also express our gratitude to DP4M for the grant No. 338/P4M/DPPM/ L-3311/BBI/1992; and grant from UGM/3475/ M/09/01, June 1993.

\section{REFERENCES}

1. Cossman J. Approaching the molecular genetic era of diagnostic pathology. In: Molecular genetics in Cancer Diagnosis. Elsevier, New York, 1990.

2. Solomon E, Barrow J, Goddard AD. Chromosom aberration and cancer. Science 1991; 54: 1153-9.

3. Rooney DE, Czepulkowski BH. Tissue culture methods in Human cytogenetics. In: Human cytogenetics. A practical approach. Washington: IRL Press, 1992: 1-36.
4. Medical Record Sardjito Hospital, 1994.

5. Sutaryo. Incidence and management therapy of leukemia in Sardjito Hospital. Scientific Meeting of Oncology Group, 1993.

6. Soenjoyo. Incidence leukemia in Semarang. Kopapdi, Semarang, 1990.

7. Catovsky D, Mutates E, Buccheri V, Shetty V, Haslip J, Yoshida N, et al. A classification of acute leukemia for the 1990s. Ann Hematol 1991; 62: 16-21.

8. Bain BJ. Immunological, cytogenetic and other markers. In: Leukemia Diagnosis A guide to the FAB classification. London: Gower Medical Publishing, 1990.

9. Le Bean. Cytogenetic analysis of Hematological malignancy disease. ALT Cytogenet 1991; 39: 441.

10. Third International Workshop on Chromosome in Leukemia. 1980

11. Benn PA, Perle MA. Chromosome staining and banding techniques. In: Human cytogenetics. A practical approach. Washington: IRL Press, 1992; 57-83.

12. Secker-Walker LM, Chessels JM, Stewar EL, Swansbury GJ, Richards S, Lawler SD. Chromosomes and other prognostic features in acute lymphoblastic leukemia; a long term follow up Brit J Haematol 1989; 72: 336.

13. Watt JL. Stephen GS. Lymphocyte culture for chromosome analysis: In: Human cytogenetics, A practical approach. Washington: IRL Press, 1987.

14. Raimondi SC, Behm FG, Robertson PK, Pui C-H, Rivera GK, Murphy SB, et al. Cytogenetics of childhood T-cell leukemia. Blood 1988; 72: 1560 .

15. Saglio G, Guerrasio A, Ponzetto C, Zaccaria A, Testoni R, Celso B, et al. Variability of the molecular corresponding to the presence of a Philadephia chromosome in human hematologic malignancies Blood 1988; 72: 1203.

16. Kapelushnik J, Dube I, Wilson P, Grunberg M. Acute lymphoblastic Leukemia with $(4 ; 11)$ translocation after osteogenic sarcoma. Cancer 1991; 67: 2887-9. 